\title{
УДК 316.2Бек
}

\section{ІДЕЇ УЛЬРІХА БЕКА В КОНТЕКСТІ СУЧАСНИХ МЕТОДОЛОГІЧНИХ ПОШУКІВ У СВІТОВІЙ СОЦІОЛОГІї}

Кононов Ілля Федорович - доктор соціологічних наук, профессор, завідувач кафедри фрілософії та соціології Луганського національного університету імені Тараса Шевченка, пл. Гоголя, Старобєльск, 192703, Луганська обл., Україна, kononov_if@ukr.net, ORCID ID https://orcid.org/0000-0002-9253-6261

Kononov Illya - Doctor of Science (Sociology), Full Professor, Head of the Department of Philosophy and Sociology, Lugansk National Taras Shevchenko University, 1, pl. Gogol, Starobelsk, Lugansk region, 92703, Ukraine, kononov_if@ukr.net, ORCID ID https://orcid.org/0000-0002-9253-6261

У статті здійснено реконструкцію системи і методу німецького соціолога Ульріха Бека. Показана важливість цієї роботи в методологічній ситуації, яка склалася в сучасній соціології і зумовлена змінами в соціальному світі та четвертою науковою революцією. Значна частина понять, які входять у понятійні мережі різних парадигм сучасної соціології, сфрормувалися ще під час другої наукової революції. Окрім того, соціологи, досліджуючи сучасність, стикаються з впливом позанаукових обставин, в якості яких виступають глобальні загрози, тиск правлячих класів та ін. Ульріх Бек збагатив світову соціологію концепціями суспільства ризику, Другого модерну, космополітизму. Важливе значення має його критика методологічного націоналізму. Його заклик до подолання «понять-зомбі» й сьогодні зберігає свою актуальність. Разом з тим, німецький соціолог, закликаючи до нової утопії, бачив шлях до космополітичної фредерації держав з розділеним суверенітетом у налагодженні співпраці між капіталом, державами і громадянським суспільством. Проте реальних механізмів цієї співпраці він запропонувати не зміг. Для прогресивного зрушення проблематики сучасності корисним може бути синтез ідей теорії Другого модерну, соціології творчого марксизму, світ-системного аналізу і екологічної соціології. До цього часу ці традиції розділені бар'єрами нерозуміння і конкуренції за інтелектуальну новизну. В теорії Другого модерну вадою $є$ контекстуальна залежність від поточної політичної ситуації. У. Бек створював свої тексти як коментарі до поточних процесів. Для ідейного синтезу необхідно не просто відтворити хід думки соціологів, а представити їхні ідеї у вигляді зв'язних концепцій у контексті вимог нової методологічної ситуації. Другий модерн і така його характеристика, як глобалізація можуть розглядатися як етап у розвитку світової капіталістичної системи. Ідея суспільства ризику може резонувати з розробками екологічної сочіології. Критика неолібералізму в соціології творчого марксизму може надати більшу предметність ідеї космополітизму. Але для цього необхідно зробити реконструкцію понятійних рядів цих дослідницьких напрямків, їхніх методологічних настанов у зв'язку з фрілософськими основами притаманного ним метасоціологічного знання.

Ключові слова: Ульріх Бек, методологія, Модерн, Другий модерн, суспільство ризику, космополітизм, методологічний націоналізм.

The article reconstructed the system and method of the German sociologist Ulrich Beck. The importance of this work in the methodological situation in modern sociology is shown. This situation is due to changes in the social world and the fourth scientific revolution, which takes place in science in general. A significant part of the concepts included in the conceptual networks of various paradigms of modern sociology were formed during the second scientific revolution. In addition, sociologists, who investigate the Modernity, face the impact of unscientific circumstances, such as global threats, pressure of the ruling classes, and others. Ulrich Beck influenced world sociology with concepts of risk society, Second Modernity, cosmopolitanism. His critique of methodological nationalism is important. His call for overcoming "zombie concepts" remains valid. At the same time, the German sociologist, calling for a new utopia, saw the path to a cosmopolitan federation of states with divided sovereignty in establishing cooperation between capital, states, and civil society. He could not offer any real mechanisms for this cooperation. For progressive shifts in the problems of modernity, the synthesis of the ideas of the Second Modern, the sociology of creative Marxism, the world-systems analysis and ecological sociology can be useful. By this time, these traditions are divided by barriers of incomprehension and competition for intellectual novelty. In the theory of the Second Modern, the disadvantage is also a strong contextual dependence on the current political situation. $U$. Beck created his texts as comments to current processes. For ideological synthesis, it is necessary not only to recreate the course of thoughts of sociologists, but to present their ideas in the form of coherent concepts in the context of the requirements of a new methodological situation. The Second Modern and its characteristics such as Globalization can be considered as a stage in the development of the world capitalist system. The idea of a Risk Society can resonate with the development of Environmental Sociology. Criticism of neoliberalism in the sociology of creative Marxism can provide greater objectivity to the idea of cosmopolitanism. But for this, it is necessary to reconstruct the conceptual series of these research directions, their methodological guidelines in connection with the philosophical foundations of their metasociological knowledge.

Keywords: Ulrich Beck, methodology, Modern, Second modern, risk society, cosmopolitanism, methodological nationalism.

(C) Кононов I. Ф., 2019

DOI: 10.26565/2227-6521-2019-42-02 


\section{Частина I \\ Система і метод Ульріха Бека}

«У иих умовах нового значення набуває соиіологія як дослідження того, що означає людське життя в пастиі, на яку перетворився світ»

(Ульріх Бек) [1, с. 27]

\section{Актуальність творчої спадщини Ульріха Бека}

У сучасній соціології формується певна методологічна стурбованість $[2 ; 3 ; 4]$. Це можна пояснити двома факторами. 3 одного боку, соціальний світ суттєво змінився за останні 50 років. На рівні здорового глузду стала зрозумілою невідповідність багатьох соціологічних теорій новій реальності. Звідси виникла мода на всілякі термінологічні покручі («гібридна війна» - один з останніх). 3 іншого боку, вся наука переживає четверту глобальну наукову революцію [5, с. 320-324]. Окрім усього іншого, вона пов'язана 3 усвідомленням активної ролі колективного суб'єкта в пізнанні, з неможливістю вилучити його вплив 3 результатів пізнання. Кожна наука, в тому числі і соціологія, реагує на цю ситуацію в міру наявних у неї ресурсів. У будь-якому випадку нова методологічна перспектива не може виникнути нізвідки, будучи плодом зусиль якогось геніального розуму. Тому важливо фіксувати і розробляти паростки нових методологічних ідей, які вже з'явилися в соціології. Як здається, у цьому зв'язку перспективно звернутися до спадщини німецького соціолога Ульріха Бека $(1944-2015)$, адже він був надзвичайно чутливим до змін у суспільному житті і вважав, що ці зміни повинні корелюватися зі змінами в методології його пізнання. Корисно зробити реконструкцію його ідей в контексті сучасної методологічної ситуації.

Але спочатку спробуємо реконструювати сучасну методологічну ситуацію. Наукове знання існує на трьох рівнях: метатеоретичному, теоретичному і емпіричному. На нинішній момент в соціології склалася ситуація, коли переважає знання саме третього з названих рівнів. При цьому продукування емпіричного знання зумовлюється далеко не в першу чергу вимогами пізнання суспільства. Після так званої «геллапівської революції» [6, с. 114-207] соціологія стала одним з інститутів демократичного суспільства, забезпечуючи потреби управління ним. 3 цим пов'язане не лише обгрунтування вибіркового методу отримання первинної соціологічної інформації в масових опитуваннях, але і суттєва методологічна переорієнтація всії соціологічної науки. Перспективу для неї задав Роберт Мертон, запропонувавши концепцію «теорії середнього рангу» [6, с. 188-208].

Емпірично орієнтовані теорії сприяли швидкому нарощуванню нового емпіричного знання, калейдоскопічній зміні теоретичних концепцій. Останні, насправді, в більшості були концептуалізаціями емпіричного рівня, які лише приймалися за теорію. Достатньо згадати пояснення електоральної поведінки або навіть концепції, які претендували на значно більше («авторитарна особистість» та ін.). Завдяки цій методологічній перспективі соціологія стрімко диференціювалася на (в перспективі) нескінченну кількість спеціальних або галузевих соціологій. Р. Мертон хотів запобігти розтяганню соціології між полюсами соціальної психології та соціальної філософії, але, як наслідок, ми отримали занепад соціологічної теорії як спільного орієнтира усіх учених у предметній царині нашої науки.

Теорія передбачає не концептуалізацію емпіричних результатів, а створення абстрактнопонятійних моделей дійсності. Для них потрібні ідеальні об’єкти. Серед класиків соціології цією проблемою найбільше займався Макс Вебер, який запропонував концепцію «ідеальних типів» [8, с. 495499]. Це не є єдиним шляхом створення ідеальних об’єктів для соціологічної теорії. Проблема їхнього конструювання вирішується з використанням метатеоретичного рівня знання, який в соціології $є$ надто непевним. Справа в тому, що метатеоретичний рівень пов'язує власне наукову теорію 3 філософією. В соціологічному ж співтоваристві до цього часу розповсюджені антифілософські настрої, які колись так, здавалось би, переконливо концептуалізував Еміль Дюркгайм [9]. Антифілософські настанови винні в тому, що соціологи користуються поняттями 3 нечітким змістом, а методи отримання первинної інформації обгрунтовуються радше на рівні математики і статистики, а не власне на рівні соціологічної метатеорії [10].

В'ячеслав Стьопін показав, що будь-яка наука повинна свідомо ставитися до своїх основ, які $є$ трьохкомпонентними і складаються з ідеалів і норм наукового пізнання, наукової картини світу та філософських підвалин науки [5, с. 191]. Цим створюється первинна наукова програма, яка задає орієнтацію вчених. Вона існує через категоріальну мережу: «Будь-яке пізнання світу, в тому числі i наукове, в кожну історичну епоху здійснюється у відповідності 3 певною «мережею» категорій, які фіксують певний спосіб членування світу і синтез його об'єктів» [5, с. 209].

Варто наголосити, що особливого значення метатеоретичне знання набуває в епохи наукових революцій. В. Стьопін вважав, що наукові революції бувають «глобальні» (охоплюють всю науку) i «локальні» (радикально змінюють окремі науки). Глобальні революції, до яких належить і четверта, яка 
розгортається на наших очах, не є раптовими стрибками [5, с. 285]. Вони починаються з переосмислення наукової картини світу, що потім відображається на методологічних засадах різних наук. Для соціології революційні зміни в теорії збігаються з радикальними змінами в суспільному житті («молодіжний бунт» в Західній Свгопі та США наприкінці 1960 - початку 1970 рр., в’єтнамська війна і протести проти неї, наступ неолібералізму, криза лівого руху, криза соціалістичного табору та ін..). 3 цим пов'язані радикальні новації в американській соціології, які з'явилися в 1970-ті роки. Тоді були розроблені оригінальні версії неідеологічного історичного матеріалізму (світ-системний аналіз, теорія революції Т. Скочпол, теорія виникнення держави Ч. Тіллі та ін.) [11, с. 373-374]. Ці версії історичної соціології для пояснення сучасності користувалися надзвичайно довгими історичними екскурсами. Але стрімкий потік змін, який охопив світ, вимагав більш швидкої і безпосередньої реакції соціологів. Сформувалися і відповідні платформи для такої реакції: постмодернізм і опозиційна до нього теорія Другого модерну. Заслуга у формування останньої теоретичної позиції переважно належить Ульріху Беку. Його праці суттєво вплинули на рельєф світової соціології. Але цей вплив до цього часу є частковим. Він стосується концепцій Другого модерну і суспільства ризику. Є ще декілька ідей та образів, які з'являються в сучасному дискурсі, скажімо, метафора «примарного вокзалу». Навіть його головна ідея Другого модерну стала більш популярною завдяки іншому соціологу - Зігмунту Бауману [12].

За життя про теорію У. Бека писали досить багато в різних країнах. Після смерті соціолога його інтелектуальна спадщина на певний час відсунулася в тінь. Це, мабуть, природно, і так відбувається 3 більшістю вчених. Від них очікували весь час нового слова, і це підтримувало до них інтерес. Смерть поклала край цим очікуванням. Тепер відбувається /мусить відбутися / може відбутися імплементація його ідей в основний масив соціологічного знання. Проте важливо, щоб це здійснювалося через конструктивну критику.

До цього часу найбільшу увагу світового соціологічного співтовариства привертали такі грані теорії У. Бека, як космополітизм [13-23], теорія Другого модерну і рефлексивної модернізації [24-27], теорії суспільства ризику і глобалізації [28-33].

Засвоєння ідей У. Бека обтяжене декількома обставинами. По-перше, його тексти, як і тексти більшості соціологів, занурені в плинний контекст певного часу. Вони були коментарями до сучасності. Німецький соціолог так і казав в одному 3 інтерв’ю: «Для мене основне завдання соціології - це теоретично спрямований i історико-емпірично обгрунтований діагноз часу» [34, с. 5]. Тепер треба «вилущите» ті ідеї, які залишаються важливими і надалі. По-друге, У. Бек займав певну політичну позицію і намагався вплинути на розвиток СС у напрямку федералізму (участь у групі Спінеллі в Свропарламенті - The Spinelli Group). У партійній боротьбі ідеї сприймаються не як наукові висновки, а як позиції політика. По-третє, німецький соціолог постійно рухався по межі між соціологією і філософією. 3 цим пов'язаний навіть стиль його текстів, який ускладнює сприйняття достатньо простих думок. Крім того, позиція «від чистого розуму» часом приводила його до висновків крайнього характеру, і навіть ідея вищої цінності прав людини починала виглядати загрозливо по відношенню до гуманізму.

Здається, що відмічена складність спадщини Ульріха Бека може негативно вплинути на функціонування його ідей у світовій соціології. В першу чергу, це стосується найціннішого - його методологічних ідей. Для нього вони були предметом постійної турботи, адже, на його думку, зараз соціологія оперує пустими поняттями, або «поняттями-зомбі». Вони хибно орієнтують соціологію в цілому. Навіть емпіричні індикатори визначаються невірно. Саме в методологічній переорієнтації він вбачав головне завдання концепції Другого модерну: «Головна мета розрізнення Першого і Другого модерну має подвійний характер: по-перше, підняти питання про необхідність нових понять і систем відліку, по-друге, критично переглянути конвенційну соціологію як соціологію пустих термінів, соціологію-зомбі» [35, с. 32]. Явно маючи перед внутрішнім поглядом образ І. Канта, У. Бек писав: «Космополітизм означає (в переносному сенсі), що Птолемеєва система національно-державного світу переживає коперніканське відкриття; відмінності між національним і інтернаціональним, периферією i центром, внутрішньою і зовнішньою політикою, економікою і пануванням втрачають свою провідну роль i потребують нового пояснення для Другого модерну, особливо щодо відмінностей «глобальний локальний», «універсальний - партикулярний» (або їх неототожнення)» [36, с. 278].

За життя У. Бек опублікував значну кількість праць як одноосібно, так і з колегами. Його книжки рецензувалися і перекладалися по усьому світу. Зараз, коли ми можемо оглянути спадщину У. Бека як завершену цілісність, виникає питання: чи не буде забута саме методологія автора? Чи не зіткнемося ми в цьому випадку з тим, що М. Розов назвав «законом Страхова». Геолог і геохімік Микола Страхов свого часу писав: «Доля програмних статей загалом, за дуже рідкісним винятком, однакова: якщо цю програму не реалізує сам автор іiі (разом з колективом) або ж будь-хто з учнів, які дійсно пройнялися ідеями вчителя, то вона швидко забувається, а реальна наукова робота йде зовсім іншим річищем» [37].

Метою цієї статті і є з'ясування того, чи створює теоретичний доробок У. Бека особливу методологічну перспективу, яка здатна забезпечити прогресивне зрушення проблем в сучасній соціології. 
Для іï реалізації пропонується такий шлях: спочатку ми реконструюємо, так би мовити, «доктринальний спадок» ученого, його систему, потім спеціально зупинимося на методологічних питаннях у його творах, розглянемо занурення його методологічних орієнтирів у класичну спадщину і подивимося на розвиток беківського теоретизування в полеміці з колегами. Завершимо розгляд питанням про можливість синтезу методологічних ідей Ульріха Бека та методологічних пошуків в інших напрямках сучасного соціологічного теоретизування.

\section{Система: між соціологічною емпірією і вимогами чистого розуму}

В одному з інтерв’ю У. Бек своїми головними працями назвав «Суспільство ризику» та «Влада і контрвлада в добу глобалізації» [34 с. 22]. Я б обов'язково до цього переліку додав також монографію «Що таке глобалізація?», текст якої є одним із найбільш стилістично прозорих у доробку автора. Книгу «Влада і контрвлада у добу глобалізації. Нова світова політична економія» можна вважати його Маgnum opus. ${ }^{2}$. Варто сказати, що українською і російською мовами перекладено на цей час незначну частину монографічного доробку німецького автора. У статті про Ульріха Бека в німецькомовній Вікіпедії називають 28 його найважливіших, на думку авторів, книг. Вони написані як одноосібно, так і у співавторстві, і охоплюють коло проблем від соціології професій до кризи влади в ЄС. Декілька праць були підготовлені спільно з дружиною Елізабет Бек-Гернсхайм. Відносно повне уявлення про бібліографію творів Ульріха Бека німецькою, англійською, шведською, датською та норвезькою мовами станом на 2002 р дає публікація Аллана Крістіансена в спеціальному номері журналу «Slagmark» [38]. Виступаючи на семінарі 20 червня 2012 р. в Горбачов-Фонді та в Інституті Кеннана німецький соціолог дав уявлення про свій доробок наступного десятиліття [39].

Чи можна $з$ десятків книг і сотень статей Ульріха Бека вилучити ту сукупність суджень про соціальний світ, яку ми можемо вважати його системою? Скажу так, що це непросто, адже тексти німецького соціолога переобтяжені поточною інформацією, політичними пристрастями, його теоретичні конструкти знаходяться в контекстах поточних аналізів. Але при цьому він збурював дискусії в академічних колах, завдяки яким соціологія стала говорити іншою мовою. Поняття, які він використовував, набували все нових конотацій від публікації до публікації. Це дає підстави для пошуків і реконструкції теоретичної системи У. Бека. Але це - не застигла система, а динамічна, що і відображається в постійному розвитку її понять.

Власне, праці У.Бека демонструють, як актуально розвивається мова соціології. Німецький соціолог вводив терміни, які, якщо скористатися мовою програмістів, виконували функції операторів, перебудовуючи всю програму. Мабуть, першим таким терміном, який стосується того, що можна назвати системою У. Бека, був термін «ризик».

Він писав, що ризики «...мають справу з передбаченням, з руйнуваннями, які ще не настали, але насуваються, які сьогодні реальні саме в цьому значенні. <..> В цьому сенсі ризики передбачають майбутнє, прихід якого слід затримати» [40].

Поняття ризику на моє розуміння пов'язане 3 модерном. «Констатація ризику базується на математичних можливостях і суспільних інтересах перш за все там, де вони можуть впевнено заявити про себе завдяки технічним засобам» [40]. Становлення модерну було пов'язано з винайденням форм роботи 3 ризиками, з відповідним суспільним договором про безпеку, а в більш вузькому сенсі - зі страхуванням. «"Обчислення ризиків“є єднальною ланкою між природничими, технічними і суспільними науками. <...> ...Обчислення ризиків - це приклад своєрідної етики без моралі, математичної етики технологічного часу. Успіх обчислення ризиків, вірогідно, не був би можливим, якщо б він не давав деяких вагомих переваг» [41, с. 163]. Але зміна характеру ризиків призвела до розколу в Модерні. «...3 середини цього століття [автор мав на увазі ще XX ст.. - I.К.] соціальні інститути індустріального суспільства зіткнулися 3 історично безпрецедентною можливістю знищення всього життя на планеті в результаті прийняття певних рішень. Це відрізняє нашу епоху не лише від ранньої стадії індустріальної революції, але і від решти культур і суспільних форм, як би не розходилися вони і не суперечили одна одній в деталях» [41, с. 165].

Мислення Ульріха Бека, що сформувалося на традиціях німецької філософії, $є$ наскрізно діалектичним. Поняття ризику він перетворює на знаряддя виявлення діалектики Модерну. Завдяки цьому змінюється саме уявлення про наукову раціональність. «Усвідомлення ризиків модернізації затвердилось, долаючи спротив наукової раціональності» [40].

Ризики створюють особливий тип управління і самоуправління поведінкою людей в сучасному суспільстві - управлінням за допомогою страху перед можливим майбутнім. «У суспільстві ризику минуле втрачає здатність визначати сучасність. На його місце висувається майбутнє як щось неіснуюче, як конструкт, фікція в якості «причини» сучасних переживань і вчинків» [40]. В іншому місці він писав: «Специфічна онтологія ризику знайшла своє вираження в подоланні відмінностей між реальністю і

\footnotetext{
${ }^{1}$ Шкода, що видання іiї перекладу українською мовою містить багато помилок.
} 
репрезентацією - а це ключовий фактор у сприйнятті реальності, щуо знаходиться у процесі становлення» [42, c. 17].

Сучасні ризики - це не просто випадкові події природного чи суспільного походження, які несуть загрозу і які потрібно передбачити для оцінки і попередження. Вони виробляються всією суспільною системою і тим самим є продуктом колективної безвідповідальності. Ризики не тільки продукуються системою, але й стають надзвичайно прибутковим бізнесом. Скажімо, нові хімічні речовини викликають нові хвороби, для подолання яких виробляються нові ліки, які викликають побічні ефекти, для подолання яких потрібні нові ліки. «Завдяки дефініціям ризиків, що змінюються, можна створити абсолютно нові потреби, a, отже, і ринки» [40]. Таким чином, «...розповсюдження і примноження ризиків жоднім чином не пориває з логікою розвитку капіталізму, а скоріше піднімає цю логіку на новий щабель. Ризики модернізації - це big business, великий бізнес. Вони являють собою те, що шукають економісти - запити, які неможливо задовольнити» [40].

Ризикам, що набули глобальності, неможливо запобігти на локальному рівні. «Виживуть лише ті, хто розуміє і проводить національну політику космополітичним чином» [42, с. 28]. Ця обставина тисне на модальність суспільних відносин, на соціальні структури усіх країн. 3 одного боку, «історія розподілу ризиків показує, що ризики, як і багатство, розподіляються за класовою схемою, тільки у зворотному порядку; багатство зосереджується у верхніх шарах, ризики - в нижніх. Вірогідно, ризики не знищують, а посилюють класове суспільство» [40]. 3 іншого боку, ризики всіх на планеті ставлять в одну соціальну позицію. «В кінцевому підсумку тиску цивілізаційних ризиків, що наростає, піддаються друг і ворог, Схід і Захід, верх і низ, місто і село, чорні і білі, Південь і Північ. Суспільства ризику - не класові суспільства, але цього мало. Вони несуть в собі базисну демократичну динаміку розвитку, щзо підриває кордони, за допомогою якої людство заганяється в уніфіковану ситуацію цивілізованого саморуйнування» [40].

Ризикогенне суспільство не може існувати у формах, які склалися в період першої модернізації. Головна 3 них - це національна держава. 3 нею пов'язані стосунки праці і капіталу, форми сім'ї i домогосподарств, інститути передачі соціальної інформації та ін. Ці форми не просто стають неефективними. Національні політичні інститути загрожують самому існуванню людства. «На початку XXI сторіччя термін condition humana може бути зрозумілим тільки на глобальному рівні, а не національному або локальному» [35, с. 25]. Модерн починає руйнуватися. «Негативність модерну, як і його свідомості, - не просто позиція, не ідеологія трагічного. Саме історична свідомість національного модерну зумовила накопичення морального, політичного, економічного й технічного потенціалу катастроф, як у справжній лабораторії з книжки 3 жахливими картинками, лабораторії, що не знає співчуття і не зважає на можливість самознищення. Про це свідчать масові могили жертв ХX століття світових воєн, голокосту, атомних бомб у Хіросімі й Нагасакі. Список абсолютного зла нескінченний. Не варто лити сльози з приводу кінця цъього модерну» [36, с. 291].

Руйнування певних форм Модерну не веде до виходу за його межі. Перший модерн змінюється Другим модерном. При цьому погляди У. Бека з його приводу не були стабільними. Він розглядав Другий модерн і як перспективу, і як наявний стан. «Те, що уявляється розпадом, могло б, якщо б вдалось подолати ортодоксальність поглядів, які призвели до краху Першого модерну, стати початком перетворення в Другий модерн» [1, с. 22]. Перехід до Другого модерну можливий у формі рефлексивної модернізації. Вона передбачає вироблення нових форм життя через критику тих, які несуть загрози. «...Рефлексивна модернізація - це амбівалентна, але реалістична критика розуму, який звів себе на пасивний рівень інструменту» [42, с. 18]. Соціолог навіть пише про необхідність нового Просвітництва: «Необхідне друге Просвітництво, завдяки якому наше розуміння, наші очі і очі наших інститутів розкрилися б і побачили усю незрілість (в якій самі і винні) першої індустріальної цивілізації разом зі всіма породженими нею небезпеками» [1, с. 175].

Ідея рефлексивної модернізації відкриває перспективу виникнення множинних i навіть альтернативних модернів. В принципі, соціалізм і був альтернативним модерном по відношенню до капіталізму. Але у німецького соціолога альтернативні модерни розглядаються в контексті можливої спеціалізації держав на світовому ринку [36, с. 251].

Зусилля з осмислення нової реальності у німецького соціолога приводять не лише до діалектичних суперечностей. У його текстах виникають і формально-логічні суперечності, яких він не помічає. Так, говорячи про страх, породжений ризиками, як про рушійну силу прийняття рішень, він вдається до антимарксистської риторики. «Неомарксистська критика капіталістичної світової системи позбавилася будь-якого утопічного імпульсу, будь-якої політики надії і фантазії. Адже цьому аналізу не відповідає, 3 цього аналізу не випливає жоден суб'єкт» [1, с. 172]. Подібна риторика часто створює епістемологічне тло аналізу у творах У. Бека. Вона стала передумовою для одностороннього висновку, який, разом 3 тим, автору дуже подобався і який він повторював багато разів: «У класових суспільствах буття визначає свідомість, в той час як в суспільстві ризику свідомість визначає буття» [40]. Але реально в суспільстві ризику повна рефлексивніть неможлива, адже свідомість включається у виробництво ризиків: «Ризик і 
незнання волають про забезпечення безпеки, а ведуть до нових небезпек і невпевненостей, змушуючи тикатися наосліп у тумані ненадійності і незнання» [42, с. 13]. В іншому місті читаємо: «Ми маємо справу 3 динамікою, в якій приріст наукового знання часто веде не до безпеки, а до посилення когнітивної непевності й нормативної ненадійності» [36, с. 306]. Отже, свідомість виявляється цілком зануреною в буття, адже «...виникає розуміння, що транснаціональні соціальні простори можуть загадковим, здатним викликати численні конфлікти чином створюватися «за спиною людей» як наслідок небажаних, оскаржуваних, таких, щзо витісняються, загроз» [1, с. 75].

Нове суспільство просякнуте конфліктами, які формуються в силових полях головних напруженостей. У. Бек називає три осі конфліктів: екологічну, фінансову і терористичну. Але «... світова економіка, без сумніву, - найважливіше джерело виробництва невпевненості і ненадійності у світовому суспільстві ризику» [42, с. 19].

Світова економіка вирвалася за межі контролю національних держав, викликавши кризу в їхньому існуванні, зробивши їх слабкими для здійснення фіскального, взагалі фінансового контролю. 3 цими суперечливими процесами пов'язана провідна риса Другого модерну - глобальність. Німецький соціолог для опису цієї реальності вважає за необхідне зробити аналіз понять «глобалізм», «глобальність» і «глобалізація». Позитивну характеристику нової якості дає друге поняття: «Під глобальністю розуміється те, що ми давно вже живемо у світовому суспільстві в тому сенсі, що уявлення про замкнені простори перетворилося у фікцію» [1, с. 25]. Останнє поняття характеризує процесуальність глобальності: «...Глобалізація має на думці процеси, в яких національні держави та їхній суверенітет вплітаються в павутину транснаціональних акторів і підкорюються їхнім владним можливостям, їхнім орієнтації та ідентичності» [1, с. 26]. Глобалізм $\epsilon$ синонімом ідеології неолібералізму, яку У. Бек визначає як «імперіалізм економічної складової» [1, с. 24].

Другий модерн вимальовується як нерівноважний, контингентний, суперечливий, конфліктний. Влада тут існує в єдності з контрвладою. «Суттєвою ознакою відмінності між Першим і Другим модерном $\epsilon<\ldots>$ незворотність досягнутої глобальності. Це означає: ми живемо в багатовимірному, поліцентричному, контингентному, політичному світовому суспільстві, в якому транснаціональні i національно-державні актори грають одне з одним в кішки-мишки. Глобальність і глобалізація мають на думці, таке: не-світову державу. Точніше: світове суспільство без світової держави і без світового уряду. Виникає глобально дезорганізований капіталізм, адже не існує жодної гегемоністської влади і жодного міжнародного режиму - ані економічного, ані політичного» [1, с. 200]. Глобалізація здійснюється в єдності з індивідуалізацією. Останній аспект в цій статті я розглядати не буду.

Сучасний світ, за У. Беком, увійшов у глобальну турбулентність. Це пов’язано з тим, що в ньому діють правила різних типів суспільного устрою - Першого і Другого модернів. Перший модерн територіальний, Другий - глобальний. У першому діє принцип національного суверенітету, в другому розділеного суверенітету. В першому атрибутом держави $є$ територіальність, в другому - вона зобов’язана iї позбутися. На цей час різні правила накладаються одне на одне і викликають світову хаотизацію. Дії світових акторів в описаній ситуації він називав метагрою. У.Бек писав: «У метагрі я розрізняю, підходячи спрощено, три організації: держави, всесвітньо-економічні актори, а також актори глобального громадянського суспільства» [36, с. 37]. Правила гри змінюються в іiї процесі. Але право на зміну правил не належить усім учасникам: «Зміна правил гри була й лишається революційним привілеєм капіталу. Решта приречена погоджуватися 3 цим» [36, с. 41]. Отже, привілейованим учасником цієї мегагри $є$ капітал (його іпостасі - ТНК, транснаціональні банки, транснаціональні економічні організації). В цілому ж метагра є сліпою для усіх акторів, які в ній задіяні. Сама гра веде учасників, а не вони грають у неї в традиційному сенсі. Зрозуміло, що гра не є суб'єктом.

У. Бек пише, що сучасний капітал прагне до автаркії. Під цим твердженням слід розуміти, що економіка, вирвавшись за межі держави, не може контролюватися національним правом. Але капітал не може жити зовсім без правил. Тому концерни створюють власну правову систему міжнародного рівня. Так, за спільною угодою створюються третейські суди для вирішення економічних суперечок. Вони формують власну нормативну базу, яка прямо не легітимізується державами. «Наслідком цього є те, що організація політичного панування, що в добу Першого модерну керувалася винятково правилами, принципами і методами національної держави, у Другому модерні трансформується та плюралізується зсередини. «Управління» у сенсі фактичного розв'язання проблем дедалі частіше здійснюється у приватний спосіб. <..> Тому транснаціональні підприємства перетворюються на приватно-економічні квазідержави, що, з одного боку, ухвалюють обов'язкові для колективу рішення, а, з другого, - зазнають мутації, перетворюючись на фіктивні, віртуальні організації, що наділяють себе правом ухвалювати рішення. Старі підприємства регулювалися через ринок та ієрархії, їхні влада і рішення визначалися i обмежувалися економічно, що знімало питання легітимізації. Але підприємства як квазідержави мають ухвалювати також політичні рішення, і вони одночасно залежать від угод і довіри, внаслідок чого вони все більше стають залежними від легітимізації» [36, с. 123-124]. 
Автаркія капіталу небезпечна для майбутнього людського роду. Вона може виглядати благодатною лише у фантазіях потужно рекламованої Айн Ренд. Їй здавалося, що благодійним є ринковий егоїзм, а не колективізм. Ї̈̈ думки висловлює головний герой роману «Джерело» Говард Рорк: «Найперше правило землі - це правило его. Найперший обов'язок людини - обов'язок перед собою. Ї̈і моральний обов'язок - ніколи не співвідносити свою головну ціль з іншими» [43, с. 739]. В час написання роману ці слова були спрямовані проти тоталітаризму. Але в наш час вони стали суголосними неолібералізму. Практика останнього продемонструвала, що таким шляхом насправді занепадає суспільне благо і без обмежень зростає соціальне розшарування.

У. Беку не подобалися вчені і політичні діячі, які лише критикували сучасність. Він сповідував принцип «зробити проблему джерелом ї̈ розв'язання» [36, с. 231]. Для протидії руйнівному впливу неолібералізму У. Бек пропонував стратегію реполітизації політики. Це означає, що через космополітизацію держави повинні повернутися в сучасний світ як важливі гравці, які мусять забезпечити соціальну справедливість. Шлях до цього - створення космополітичних держав, держав 3 розділеним суверенітетом: «Кооперативні держави діють і формуються в союзі, в мережі міждержавних угод за принципом, згідно з яким втрату влади дій окремими державами може компенсувати лише укладання міждержавних союзів держав та їхнє розширення» [36, с. 263]. Таким чином, німецький соціолог пропонував державам запозичити логіку дій транснаціональних концернів і тим самим створити умови для приборкання глобального капіталізму.

Тут варто повернутися до розуміння У. Беком глобалізації. Він неодноразово підкреслював, що «глобалізація - це наратив про владу, а не про цифровий простір та фінансові ринки» [35, с. 43]. Капітал створив особливу стратегію влади через відмову. «Засіб примусу - не загроза вторгнення, а загроза не вторгнення інвесторів, або загроза їхнього виходу з країни. Гірше за окупацію мультинаціональними компаніями може бути лише одне - не окупаиія ними» [36, с. 97]. Для протидії цьому і потрібне космополітичне державне утворення (кооперативна федерація) з розділеним суверенітетом. Воно повинно будуватися не за принципом «або..., або...», а згідно з принципом «як, так і..» (Sowohl-als-Auch). Тільки взаємне обмеження суверенітету держав створює передумови для вирішення національних проблем. «У світі ризику націоналізм стає ворогом нації» [39, с. 57].

Створення кооперативної федерації держав - це і $є$ шлях реполітизації в сучасному світі. Німецький теоретик, як на мене, досить наївно уявляв реполітизацію як вольовий акт. При цьому суб'єкт волі невідомий. Якщо в реальності держави зараз перетворилися на знаряддя транснаціонального капіталу, то яким чином можна здійснити їхню реполітизацію? Для цього треба знайти соціальну технологію. I, думаю, вона мало чим буде відрізнятися від ленінської, яка передбачає створення достатньо герметичної партії, яка буде максимально незалежною від спокус капіталізму і стане носієм альтернативної програми розвитку. Але Бек цього не говорить, і всі його слова з цього приводу залишаються лише вправами 3 вироблення нових пустих понять.

Волю до реполітизації він пов'язував 3 новою утопією і писав: «Навіть абсолютно цинічний макіавелліст мусив би (у чому і полягає суть цієї тези), впроваджуючи свої політичні стратегії оптимізації влади, стати ідеалістом і навернутися до іншої віри. Повернення влади і повернення утопії - два боки однієї і тієї самої моделі. Отже, у рамках стратегії державної влади йдеться не про утопічний утопізм, а про утопізм владно-стратегічний; i, навпаки, мова йде про те, щоб піддати критиці неоліберальну утопію не тільки з моральної чи політичної точки зору, а й з позицій стратегій влади» [36, с. 230]. На жаль, самої утопії такого роду він для обговорення не надав.

Критикуючи неолібералізм, німецький соціолог покладався на самоочевидність такого блага, як права людини. Саме ці права повинні стати основою самолегітимізації космополітичних держав, легітимізації без демократичних процедур, але з загрозою могутнього насильства. «...Логічна фігура самообгрунтування заміщує логічну фігуру демократії. На місце демократії приходить розуміння. Той, хто на певній стадії прагматичного самообгрунтування (досі) не розуміє «блага» космополітичного порядку, не хоче цього зрозуміти, і це обертається проти нього самого. Тих, хто не розуміє, потрібно відділити. Це «потрібно» є необхідним, оскільки благо само по собі уможливлює розуміння блага, тобто провину за нетямущість слід покласти на самі нетямущі країни, етнічні й релігійні групи, партії, уряди, індивідів. Тому будь-яка критика космополітичного режиму завжди наражається на звинувачення в тому, що мова тут іде про свідомо-нетямущих, тобто злих, що заважать благому порядку» [36, с. 373]. Що з ними робити далі, автор не уточнює. А варіанти можуть бути різними. Тому теорія У. Бека може заохочувати не лише серйозні роздуми, але і політичні авантюри. Він сам писав, що «...права людини відкривають дорогу хибному космополітизму, тобто гегемонійному маніпулюванню правами людини» [36, с. 116]. Проте і про «справжній космополітизм» він інколи висловлюється з іронічною тривогою: «Мораль, економіка й армія доповнюють і посилюють одна одну, що веде до формування Великої політики кордонів і совісті, від якої знову аж стає моторошно» [36, с. 297]. 
Взагалі проблема суб'єкта реполітизації для соціолога складна. Вона, як бумеранг, повертає до нього його ж критичні зауваження, які він адресував неомарксистам. Здається, що суб'єктами змін він намагався зробити усіх учасників небезпечної метагри. 3 одного боку, він писав: «Успішною може бути лише стратегія, що включає, а не виключає державу і капітал» [36, с. 341]. В іншому місці читаємо: «Якщо звести до квазіматематичної формули, дієздатність космополітичної держави була б сумою дієздатності національних урядових організацій і бюрократій плюс свідоме використання кооперативних можливостей транснаціональних політичних мереж. Останні включають неурядові організації, наднаціональні організації, транснаціональні концерни і т. ін. Ця сума, а не лише національні ресурси, утворює можливості дії, якими володіють космополітичні інтегровані держави для того, аби відповідати національним і міжнародним викликам» [36, с. 279-280]. Далі німецький теоретик особливо наголошував, що держава повинна вступити в союз з глобальним громадянським суспільством, організації якого разом 3 тим називав «моральними підприємцями» [36, с. 305]. Що це за союз, теж залишається нерозшифрованим. Глобальному громадянському суспільству відводяться ролі акцентування суспільних проблем i вироблення нових норм діяльності.

Варто сказати, що стосовно громадянського суспільства У. Бек озвучував набридлі неоліберальні стереотипи. Правда, інколи він висловлюється досить дивно: «У перекладі на (цинічну) мову соціології це звучить так: адвокатські рухи мають піти в науку до професійних волоцюг, що досягли (особливо в добу середньовіччя) високого рівня артистизму в мистецтві самостилізації заради перетворення співчуття багатих християн на дзвінку монету» [36, с. 308]. Але такі поради, мабуть, зайві. Значною мірою глобальне громадянське суспільство (за виключенням невеликих лівих сегментів) є витвором світового капіталу. Тут не все просто і однозначно. Деякі НУО прямо створені концернами чи їхніми групами для просування своїх інтересів. Але значна частина НУО створюються для того, щоб заробляти на світових ринках послуг з просування ідей і проектів. Вони можуть і не бути жорстко прив'язаними до певних груп транснаціональної буржуазії, але діють за їхніми правилами. Через це ми не бачимо в середовищі НУО появи проривних політичних чи соціальних ідей. Вони всі борсаються в болоті неолібералізму. Вони можуть бути креативними в плані суспільних перформансів, які потім проголошуються революціями, їхні вишукані представниці (переважно!) проголошують розумні промови і навіть входять до урядів, але це не веде до зміни світового порядку денного. В практичних діях НУО використовують прекаріат (про який поговоримо далі), тим самим позбавляючи транснаціональну буржуазію небезпеки безпритульних елементів. Частина прекаріату просто спалюється в соціальних конфліктах. Так що, я не можу зрозуміти, яким чином ми можемо сподіватися на союз держав і НУО для реполітизації політики і повернення у світ політичного.

Однією з головних тем роздумів німецького соціолога були проблеми влади і легітимності. Остання проблема набула в сучасному світі великої практичної гостроти. Капітал зараз діє 3 точки зору легітимності в сірій зоні. «Ця метавлада перебуває між категоріями легального та нелегального; вона не $є$ нелегальною, проте і не є легітимно, а натомість є транслегальною; одначе вона має достатню силу для того, щоб переписати панівні на державному рівні правила в національному та інтернаціональному просторі» [36, с. 99]. Але для успіху в діяльності капітал потребує легітимності, яку може отримати лише від держави, адже «...легітимність не продається» [33, с. 302]. В іншому випадку вимальовується гобсівська перспектива всезагального насильства. Німецький соціолог писав: «Межа, після якої конфлікти метавлади переростають в акти насильства, $є$ перейденою щонайпізніше тоді, коли криза легітимності починає руйнувати державну монополію на насильство. Звідси випливає, що в метавладній грі розпадається незалежність влади і наростає небезпека нестримних вибухів насильства й ескалації насильницьких дій» [36, с. 104].

У.Бек вірно відзначає, що зараз ми не можемо легітимність розуміти виключно в категоріях М. Вебера. Справа в тому, що космополітизація - це одночасно і занепад демократії, яка передбачає територіальний принцип. Легітимізація через вибори зараз стає все слабкішою. Капітал у світовому масштабі легітимізує свої рішення через їхню ефективність. Що стосується космополітичної політики, то тут легітимізація повинна відбуватися через визнання та ефективність. Визнання є доволі проблемною процедурою. Воно відбувається внаслідок усвідомлення можливих наслідків рішень. Тобто тут політичних суб'єктів мусить осяяти чистий розум, з позиції якого вищою цінністю є права людини. В умовах загрози всезагального знищення виникає ще один вид легітимності - через усвідомлення небезпеки. Його діалектика надзвичайно складна і навіть загрозлива: «Те, що ця влада консенсусу глобального легітимного панування, яка відводить небезпеку людству, має вкрай амбівалентні наслідки, закладено в самій природі політичного. <..> Периепція загрози самогубства відкриває доступ до глобальної легітимності й до джерел консенсусної влади. Ці джерела легітимності глобального панування $\epsilon$, по-перше, адемократичними. Вони самі ухиляються від будь-якого демократичного процесу на основі своєї глобальності, проте залежать від глобального сприйняття й визнання, тобто від подачі в ЗМІ. По- 
друге, потенційно вони є також антидемократичними, оскільки з усвідомленою небезпекою для людства зростає готовність позбутися демократичних пут» [36, с. 315-316].

Багато з тверджень, які можна віднести до системи У. Бека, висловлюються ним як аналіз лише можливих побічних наслідків космополітичного ладу. Ця самокритика кидає відблиск іронії на певні його висновки. I він, начебто схаменувшись, писав: «Проте без демократії космополітизм помре, не почавши жити. Без демократії мрія людства про космополітизм - ніщзо або вже давно перетворилася на реальний кошмар» [36, с. 377]. Але далі вже без іронії У.Бек стверджував ще один «кінець історії»: «Космополітизм, якщо його домислити до кінця, є секуляризованим Божественним ладом на землі» [36, c. 377].

Можна було б написати: це вже без коментарів. Але фраза про Божественний лад на землі суперечить всьому змісту теорії У. Бека. Другий модерн виявляється дуже нестабільним станом суспільства (соціолог, визначаючи його риси, знаходить суто кризові), який не може тривати досить довго. Отже, перед нами перспектива приходу третього, четвертого і інших модернів. I соціології варто до цих змін в Модерні бути готовою. в першу чергу. методологічно.

\section{Методологія: наука і політична практика}

3 точки зору загальної методологічної установки Ульріха Бека можна назвати лівим веберіанцем, хоча він сам віддавав перевагу самовизначенню «макіавелліст». До макіавеллізму повернемося згодом. Що стосується веберіанства, то, 3 одного боку, соціолог настійливо підкреслює, що всі соціальні утворення $є$ контингентними, а, отже, історичними. Їх $\mathrm{i}$ вивчати тому потрібно через предметний історичний аналіз. Він полюбляв термін М. Вебера «констеляція» і говорив про «констеляції Другого модерну» [36 с. 159]. Разом з тим, варто відмітити, що його історичним аналізам не вистачало тієї часової глибини, яку ми бачимо у автора «Протестантської етики і духу капіталізму». Не вистачало йому i здатності тримати в пам'яті величезну кількість фактів з різних періодів історії різних народів, яка вражає у Макса Вебера. Більш того, у творах Ульріха Бека навіть мало звернень до емпірії.

Щільний опис реальності він забезпечував завдяки оперуванню ідеальними об'єктами, які створював десь на межі між соціологією і соціальною філософією. Самі ж факти, скоріше, відігравали роль ілюстрацій. Наприклад, у праці «Суспільство ризику: на шляху до іншого модерну» він спочатку теоретично дійшов до висновку про деградацію класової ситуації в країнах Заходу, а вже потім наводив цікаві факти. При цьому він мимохідь пропонував також інші підходи до такого явища, як індивідуалізація, яка і спричинила деградацію класової структури. Він писав про «ефект ліфту» у ФРН і робив висновок, що «... «класове суспільство» піднялося на поверх вище» [40]. Тільки після цього вже наводиться певна кількість фактів. Наприклад: «Якщо в 1950 р. тільки 6\% робітників могли здійснити бажання поселитися у власному житлі, то в 1968 р. їхня чисельність зросла до 32\%, а в 1977 р. - до 39\%» [40]. В іншому місці він теоретично обгрунтовує, що у випадку домінування капіталу у світовому масштабі останній розриває зв'язок з працею і втрачає свої соціальні функції. I значно пізніше соціолог наводить дані, що з Німеччини великі концерни щорічно виводять в офшори десь близько 10 млрд. євро, посилюючи тим самим податковий тиск на середній та малий бізнес, а також і на найманих працівників [36, с. 353]. Таким чином, У. Бек віддавав перевагу дедуктивним висновкам, а у М. Вебера переважала індукція.

Певне ліве забарвлення текстам У.Бека надає те, що він прагнув поєднання соціальної справедливості і ефективності в суспільному житті. Як він розумів соціальну справедливість, 3 його текстів не дуже зрозуміло. Сподівання на те, що ііі забезпеченню будуть сприяти держави, громадянське суспільство і капітал, як я вже писав, виглядають наївно. До того ж він релятивізує саму основу соціальної справедливості: «...У випадку з космополітичним порядком цінностей мова врешті-решт йде про певне визначення поняття загальнообов'язкового блага. Воно є контингентним, тобто може бути й іншим» [36, c. 372]. У певних контекстах такі твердження можуть стати маніпулятивними формулами.

Свого часу Павло Копнін писав: «Як система знання наука виступає сукупністю теорій, які описують і пояснюють певний предмет. Система знання створюється не лише для того, щоб впорядкувати і виявити у всій повноті отримані результати, але і побудувати на них метод отримання нового знання. Під час аналізу науки багато вчених зараз звертають увагу на цей іiі бік - реалізацію систем наукового знання в методі пізнання і практичної дії» [44, с. 245]. Це положення можна цілком віднести до діяльності Ульріха Бека. Як ми вже бачили, завдяки певним поняття-операторам (ризик, Другий модерн) перебудовувалася вся система соціологічних понять і виникала нова наукова програма. При цьому вона була орієнтована не лише на отримання фундаментального знання, але i на практичне політичне застосування. Частина методологічних інтенцій У. Бека є імпліцитними, а деякі він акцентував як важливі ідеї.

В останньому випадку мова йшла не просто про питання методу, а про методологічну позицію, методологічну візію суспільних процесів. Мабуть, це можна назвати методологічним принципом. В першу чергу, сказане стосується розрізнення методологічного космополітизму та методологічного націоналізму. 
Сам У. Бек засвідчував, що останнє поняття запозичив у Ентоні Сміта, і писав, що глобалізація ставить під сумнів основну передумову Першого модерну - методологічний націоналізм [1, с. 45]. Ентоні Сміт у праці «Націоналізм у XX сторіччі» відмічав, що «вивчення «суспільства сьогодні майже без сумніву прирівнюється до аналізу національних держав; принцип «методологічного націоналізму» діє на кожному рівні в соціології, політиці, економіці та історії людства в сучасну епоху» [45, с. 191]. При цьому англійський соціолог, у свою чергу, посилався на статтю Хермініо Мартінса (Herminio Martins). У подальшому У.Бек розробив концепцію методологічного націоналізму через опозицію до методологічного космополітизму.

Методологічний націоналізм був основоположним при формуванні категоріального набору соціології при ії виникненні. Згідно з ним держави / національні держави є своєрідними «контейнерами», в яких міститься суспільство 3 усіма внутрішніми диференціаціями. Скажімо, соціальна структура конституюється саме в таких просторах, а тому можна вести мову про соціальну структуру України, Росії, США, Туреччини чи Китаю. В межах соціальної структури породжуються різні характеристики відповідних суспільств: нерівність, мобільність, суспільні опінії та ін. Але в цьому випадку «...соціологічний погляд підпорядкований дисциплінуючому авторитету - владі і силі національної держави» [1, с.47]. Це викривляє оптику бачення соціальної реальності і веде до реїфікації інструментальних понять: «...Категорії державного самоконтролю стають категоріями емпіричних соціальних наук - з метою підтвердження суспільно-наукових бюрократичних дефініцій реального стану речей» [1, с. 49]. Через це не лише спотворюється картина реальності, але до неї не потрапляє значне число явищ: «...Систематично випускається з поля зору особливе - транснаціоналізація виробництва, потоків капіталу, форм життя тощо» [36, с. 57].

До вад методологічного націоналізму німецький соціолог повертався протягом всього свого творчого життя. Він підкреслював: «...Методологічний націоналізм не є якоюсь другорядною проблемою або дрібною помилкою. Він включає в себе порядок збору/виробництва даних, а також такі фундаментальні поняття сучасної соціології, як суспільство, клас, демократія, сім'я, уявне співтовариство» [39, с. 46]. Методологічний націоналізм породжує національну соціологію, в якій «... увесь світ поділяється на дві частини: «нас» і «всіх решту». Соціологія вивчає тільки «нас», тоді як «інших» вивчає антропологія, етнологія і представники подібних дисциплін» [42, с. 30]. Відтворення архаїчного поділу «ми - вони» $\epsilon$ однією з причин розбрату. В різні періоди він набував форм колоніалізму, расової теорії та ін.

Сказане стосується не лише соціології. Економічна наука також потерпає від методологічного націоналізму. Скажімо, розуміння сутності ВВП і змагання стосовно його приросту - типовий приклад. Обсяги міжнародної торгівлі теж обраховуються невірно, адже торгівля в межах ТНК також потрапляє до цієї категорії [36, с. 58]. Найбільш заражені методологічним націоналізмом політичні науки. В них характер догми набуло твердження про територіальну природу держави. Не випадково засновник сучасної геополітики Р. Челлен порівнював державу 3 лісом, який не може витягнути своїх коренів 3 грунту i рушити кудись у пошуках кращої долі [46, с. 102].

У. Бек чомусь не згадує Р. Челлена, як і не згадує інших теоретиків, які показували обмеженість суто національного погляду. А варто було б назвати хоча б ім'я А. Тойнбі, який на емпіричному матеріалі з історії Великої Британії показав, що жодна визначна подія не може бути пояснена суто внутрішніми причинами. Правда, британський історик таким чином доводив важливість цивілізацій [47, с. 85]. У німецького соціолога простір рефлексії значно ширше і охоплює усе сучасне людство. Тойнбі він згадує лише у зв'язку зі світовими містами як лабораторіями космополітизму [36, с. 286].

Методологічний націоналізм протиставляється методологічному космополітизму. В працях У. Бека вони знаходили визначення через протиставлення одне одному. Доводячи переваги космополітизму, соціолог писав, що він старший за націоналізм. При цьому німецький теоретик застосовував досить сумнівні аргументи. Так, на його думку, «в Другому модерні < ..> здійснюються ті формації політичного, які, як це не потішно, мають середньовічні риси» [1, с. 197]. В іншій праці ця думка формулюється так: «...Саме в донаціональну добу були створені та укорінилися засади й інтелектуальні традиції постнаціональної, космополітичної Європи, які сьогодні, у добу глобалізації, потрібно заново відкрити і дати їм життя, протиставивши їх мрії про вічну націю, що врешті-решт недовго протрималася» [36, с. 79]. Судження про недовгий час існування нації звучить як зловтішний докір, який до науки не має стосунку. Але німецький соціолог на цьому не зупинився. Він навіть вдався до антиісторичної концептуалізації, заявивши, що «національна держава - це незавершена держава; держава, що структурно заперечує свою моральну відповідальність за права меншин та іноземців» [36, с. 296]. Кожне історичне явище можна розцінювати в контексті своєї епохи. Оцінка його в іншому контексті спотворює саме явище.

Методологія космополітизму передбачає аналіз усіх явищ і процесів у світовій перспективі. В цьому сенсі людство сприймається як базова соціальна система. Але космополітизм не тотожний універсалізму. У. Бек, на відміну від М. Вебера, був супротивником європоцентризму. Дуже важливим у його концепції було визнання Іншого: «...Космополітизм - на противагу універсалізму - передбачає у відносинах держав $\mathrm{i}$ 
світових регіонів визнання інакшості інших. Це насамперед означає, що мають бути визнані та реконструйовані історія інших і причетність до неї самої Європи» [36, с. 289]. Звідціля і випливає, що людство як система $є$ багатошаровим утворенням, а тому в науковому аналізі і в політичній практиці повинен діяти принцип «як..., так і...». Тобто $\epsilon$ внутрішні для державних утворень причини соціальних явищ, але самі ці державні утворення можна зрозуміти лише в глобальному контексті. Думка німецького соціолога навіть більш діалектична. Космополітизм не $\epsilon$ чимось зовнішнім, хоча саме це часто асоціюється 3 прикметником «глобальне». Космополітичне $є$ моментом національного і зараз зумовлює його.

У. Бек настійливо підкреслював єдність наукового і політичного аспектів космополітичної методології: «Космополітичний реалізм (читай: макіавеллізм) дає відповідь, зокрема, на два питання. Перше: як і за допомогою яких стратегій провідні світові економічні актори нав'язують державам свої правила гри? Друге: як, зі свого боку, держави можуть відвоювати у світових економічних акторів державно-політичну метавладу та нав'язати світовому політичному капіталу космополітичний режим, який включав би в себе також політичну свободу, глобальну справедливість та екологічну сталість?» [36, c. 28]. Жодна держава світу не може впоратися з проблемами, які потрібно вирішувати задля забезпечення добробуту і безпеки громадян, тим більше задля вирішення глобальних проблем. Тому державам слід утворювати союзи з розділеним суверенітетом. Ідея розділеного суверенітету - один з головних наслідків космополітичного підходу. Космополітизація ревіталізує політику на національному рівні: «Діє закон національно-державного розподілу влади: той, хто у глобальній метагрі розігрує лише наиіональну карту, - програє. Необхідно перевернути перспективу, тобто має діяти принцип: протидія держав стає можллиою разом з їхньою транснаціоналізацією та космополітизацією» [36, с. 45].

Інколи німецький соціолог писав провокаційно, що створювало враження його загравання 3 елітними групами: «Говорячи мовою Макіавеллі, транснаціональні повноваження національної політики $\epsilon$ подвійними: вони сягають за межі національних кордонів $i$ додають в ефективності у національному масштабі, оскільки здатні підривати демократичний контроль» [36, с. 233].

Ульріх Бек не розкриває технологій формування розділеного суверенітету, а посилається на приклади EC і NAFTA [36, с. 287]. Другий приклад зараз навряд чи можна вважати релевантним [48]. У ЄС теж не все гаразд, але тут, у всякому випадку, розділений суверенітет присутній і зрозумілий.

На думку німецького соціолога, до космополітичних рішень штовхають можливі наслідки їхнього неприйняття. Це виводить соціолога на надзвичайно методологічно важливі уявлення про простір і час. Декілька слів скажу про часові координати. Я вже зупинявся на ідеї німецького вченого про детермінацію людських дій уявленнями про майбутнє. Мова велася про ризики як загрози. Для протидії страху, який може викликати ненависть і робити людей вразливими до маніпуляцій, У. Бек запропонував відродження утопії. На його думку, утопія іманентна політиці як такій, а, отже, і політичній владі. «Свідоме зречення утопії - це не тільки хвороба людського духу, а й карт-бланш на відмову політики від самої себе. Лише той, хто може надихати, завойовує схвалення і владу» [36, с. 237]. Другий модерн з його принципом рефлексивної модернізації тим більше неможливий без утопії. Вона стає основою конструктивної уяви, на яку дуже покладався німецький соціолог. Утопія розкриває «клітку модерну» назустріч майбутньому [36, с. 355]. Власне, ідея Другого модерну і набуває методологічного значення як уявлення про час-перспективу, час, який триває. 3 цим часом пов'язаний простір, який змінює і свою топіку, і навіть мірність. В цьому просторі немає зовнішнього. Вся політика тут стала внутрішньою. «Світова політика перетворилася на внутрішню світову політику, що позбавляє національну політику кордонів і засад» [36, с. 311].

Неолібералізм створив зовсім інші просторово-часові координати сучасності. Це просторовість паноптикуму: простір без перспективи змін, але з повним контролем усіх місць. Існує відповідна глобальна система, «...в якій держави, концерни й міські спільноти за допомогою агентств, що спеціалізуються на оцінці платоспроможності, оцінюються на предмет відповідності правилам «гарного» (читай: неоліберального) бюджету. На початку ХХІ століття МВФ контролює економічну політику майже кожної третьої «суверенної» держави на нашій планеті» [36, с. 324].

Рух до космополітичного федералізму не може відбутися відразу на всій планеті. У. Бек слушно вважав, що на цьому шляху можуть виникнути різні політичні рішення, а, отже, буде формуватися $\mathrm{i}$ змінюватися контингентний ландшафт світової влади. Відбувається плюралізація світу держав. Наприклад, потужні держави можуть ігнорувати потребу розділеного суверенітету і спробувати вирішити проблеми через власне перетворення на держави-наглядачі. Це такі собі світові поліцейські. Так поводяться США. Як відповідь на глобалізацію може виникнути етніцизм і етнічні держави. Неоліберальні держави - моделі активного демонтажу демократії і політики як такої. Вказані дві моделі можуть поєднуватися, і це нам нагадує українську реальність. «Так виникають «саморобні» держави, в яких поєднуються елементи декорації неоліберальної та етнічної держав» [36, с. 325]. Сам розділений суверенітет у транснаціональних утвореннях може набути різних модифікацій: від правого до лівого космополітизму.

У. Бек відверто пише, що космополітизація - це втрата державою територіальності. Якщо держави будуть чіплятися за неї, то вони безнадійно будуть програвати капіталу і громадянському суспільству. 
Тому необхідно відмовитися від територіальності держави і створити детериторіалізовані держави. Як він це мислив, залишається лише здогадуватися. Детериторіалізація держави позбавляє ії соціальних функцій. Політичні системи просто відриваються від решти суспільства. У всякому випадку все це дуже проблемно. Він думав, що відмова держави від територіальності дозволить вирішити проблеми приборкання глобального капіталізму: «Завдяки цьому стає очевидним, що ж перешкоджає політичним акторам, тобто державам і політичним партіям, знаходити і використовувати ці шанси, а саме хибні anріорі невіддільності наиіï $i$ держави, політики і території, політичної організації і національного суверенітету» [36, с. 231]. Але може статися прямо навпаки. В такі держави будуть організовуватися різні групи правлячого класу, розділяючи між собою панування над світом.

\section{Література:}

1. Бек У. Что такое глобализация? Ошибки глобализма - ответы на глобализацию / пер. с нем. А. Григорьева и В. Седельника; общ. ред. и послесловие А. Филиппова. М.: Прогресс-Традиция, 2001. 304 с.

2. Savage Mike, Burrows Roger. The Coming Crisis of Empirical Sociology. 2007. URL: https://pdfs.semanticscholar.org/b909/936b4c3d5ca8be06887ae8780df325b6e154.pdf

3. Yu Xie. Methodological contradictions of contemporary sociology. Michigan Quarterly Review. 2005. Summer. Volume XLIV, Issue 3, URL: https://quod.lib.umich.edu/cgi/t/text/text-

idx?cc=mqr;c=mqr;c=mqrarchive;idno=act2080.0044.318; view=text;rgn=main; $x c=1 ; g=m q r g$

4. Bulekbayev S. B., Temirgaliyev K. A., Lamanova A. S., Mingisheva N. A., Raikhanova A. N. Methodological crisis of contemporary social sciences: the theoretical aspect, 2017. URL: https://cyberleninka.ru/article/n/methodological-crisis-ofcontemporary-social-sciences-the-theoretical-aspect

5. Степин В. С. Философия науки. Общие проблемы. М.: Гардарики, 2006. 384 с.

6. Докторов Б. 3. Отцы-основатели: история изучения общественного мнения. М.: Центр социального прогнозирования, 2006. $488 \mathrm{c.}$

7. Мертон Р. Социальная теория и социальная структура / пер. с англ. М.: АСТ; АСТ МОСКВА; Хранитель, 2006. 873 с.

8. Вебер М. Избранные произведения / пер. с нем.; сост., общ. ред. и послесл. Ю. Н. Давыдова; предисл.

П. П. Гайденко. М.: Прогресс, 1990. 808 с.(Социологическая мысль Запада).

9. Дюркгейм Э. Метод социологии. Эмиль Дюркгейм Социология. Её предмет, метод, предназначение / пер. с фр., составление, послесловие и примечания А. Б. Гофмана. М.: Канон, 1995.

10. Кононов І. Ф. Соціологія в умовах кризи і війни: проблема методологічної спроможності. Вісник Луганського начіонального університету імені Тараса Шевченка. Соџіологічні науки / ДЗ ЛНУ імені Тараса Шевченка. 2016. №5 (302). C.5-55.

11. Дерлугьян Г. М. Как устроен этот мир. Наброски на макросоциологические темы. М.: Изд-во Института Гайдара, 2013. 400c.

12. Бауман 3. Текучая современность / пер. с англ. под ред. Ю. В. Асочакова. СПб.: Питер, 2008. 240 с.

13. Chernilo, Daniel. Social Theory's Methodological Nationalism Myth and Reality. European Journal of Social Theory. 2006. V. 9. N. 1. P. 5-22.

14. Chernilo Daniel. A Quest for Universalism Re-assessing the Nature of Classical Social Theory's Cosmopolitanism. European Journal of Social Theory. 2007. V. 10. N.1. P. 17-35.

15. Chernilo Daniel. A Social Theory of the Nation-State: The Political Forms of Modernity Beyond Methodological Nationalism. London, Routledge, 2007. 237 p.

16. Khan Shazad. How cosmopolitan is Ulrich Beck's Cosmopolitanism? URL:

https://www.academia.edu/14067685/Ulrich_Becks_Cosmopolitanism

17. Martell Luke. Beck’s cosmopolitan politics. Contemporary Politics. June 2008. Vol. 14. No. 2. P. 129-143.

18. Martell Luke. Global Inequality, Human Rights and Power: A Critique of Ulrich Beck's Cosmopolitanism. Critical Sociology. 2009. V. 35. N. 2. P. 253-272.

19. Martell Luke. Cosmopolitanism and Global Politics. Political Quarterly Autumn 2011.V.18. N. 4, P. 618-627.

20. Saito Hiro. Cosmopolitics: towards a new articulation of politics, science and critique. The British Journal of Sociology. 2015. Volume 66. Issue 3. P. $441-459$.

21. Schiller Nina Glick, Darieva Tsypylma and Gruner-Domic Sandra. 'Defining cosmopolitan sociability in a transnational age. An introduction', Ethnic and Racial Studies. 2011. V. 34. N. 3. P. $399-418$.

URL: http://dx.doi.org/10.1080/01419870.2011.533781

22. Schiller Nina Glick. Old baggage and missing luggage: a commentary on Beck and Sznaider's 'Unpacking cosmopolitanism for the social sciences: a research agenda'. The British Journal of Sociology 2010. DOI: 10.1111/j.14684446.2009.01297.x

23. Skrbis Zlatko and Woodward Ian. The ambivalence of ordinary cosmopolitanism: Investigating the limits of cosmopolitan openness. 2007. The Sociological Review. V. 55. N. 4. P. $730-747$.

24. Guivant Julia Silvia. Ulrich Beck's legacy. Ambiente \& Sociedade. São Paulo, jan.-mar. 2016. v. XIX, n. 1. P. 227-237.

25. Кравченко С. А. У. Бек: социологическое воображение, адекватное рефлексивному модерну. Соиис. 2011. № 8. С. 17-27.

26. Колісник О. В. Рефлексивна модернізація: до проблеми їі інтерпретації. Грані. 2015, лютий. № 2 (118). С. 68-72.

27. Francot Lyana M.A. and de Vries Ubaldus R.M.T. Normativity in the Second Modernity. Rechtstheorie. Berlin, 2008. N. 39. S. 1-18.

28. Bosco Estevão \& Marques di Giulio Gabriela. Ulrich Beck: Considerations on his contributions and challenges to the Studies in Environment and Society. Ambiente \& Sociedade. São Paulo, abr.-jun. 2015. v. XVIII, n. 2. P. 145-156. 
29. Guivant Julia Silvia. A Trajetória das Análises de Risco: Da Periferia ao Centro da Teoria Social. BIB, Rio de Janeiro, n. 46, 2. Semestre de 1998, pp. 3-38.

30. Jarvis Darryl S.L. Risk, Globalisation and the State: A Critical Appraisal of Ulrich Beck and the World Risk Society Thesis. Global Society, January, 2007, Vol. 21, No. 1 P. 23 - 46. DOI: 10.1080=13600820601116468

31. Pichlak Maciej. Regulating Risk and a Theory of Social Reflexivity of Law. URL: https://www.academia.edu/38383281/Regulating_Risk_and_a_Theory_of_Social_Reflexivity_of_Law

32. Sørensen Mads P. Ulrich Beck: exploring and contesting risk. Journal of Risk Research, 2017. URL: https://doi.org/10.1080/13669877.2017.1359204

33. Иванов Д. В. Эволюция концепции глобализации. Телескоп. СПб, 2002. №4. С. 3-14.

34. Социология: профессия и призвание. Интервью с профессором Ульрихом Беком. Провел В. В. Козловский. Журнал соииологии и соџиильной антропологии. 2003. Том VI. №1. С. 5-23.

35. Бек У. Космополитическое общество и его враги / пер. с англ. А. М. Хохловой. Журнал соичологии и соичиальной антропологии. 2003. Том VI. №1. С. 24-53.

36. Бек У. Влада і контрвлада у добу глобалізації. Нова світова політична економія / пер. $з$ нім. Олександра Юдіна. 2 -е видання. К.: Nika - Tsentr, 2015. 404 c.

37. Розов М. А. Теория социальных эстафет и проблемы эпистемологии. Смоленск: Смоленский гос. пед. у-т, 2006.438 с. (Библиотека международного коллоквима «Социальные трансформации»). URL: http://rozova.org/images/documents/SSRozovaTSEvIstorii.pdf

38. Christiansen Allan. Bibliografi over Ulrich Becks tyske, engelske, norske, svenske og danske udgivelser. URL: http://www.slagmark.dk/slagmark34

39. Бек У. Живя в обществе риска и считаясь с ним. Космополитический поворот / пер. с нем. В. С. Малахова. Полис. 2012. №5. C. 44-58.

40. Бек У. Общество риска: На пути к другому модерну / пер. с нем. В. Седельника, Н. Федоровой. М.: Прогресс-Традиция, 2000. 383. URL: http://web-local.rudn.ru/web-local/prep/rj/files.php?f=pf_eaaf4f79b02a78b919aca693a8e6b572

41. Бек У. От индустриального общества к обществу риска / пер. с англ. А. Д. Ковалева. Thesis. 1994. Вып. 5. С. 161-168.

42. Бек У. Критическая теория мирового общества риска. Космополитический взгляд на проблему / пер. с англ. Александра Маркова. Прогнозис. 2009. №2 (18). С. 3 - 32.

43. Ренд Айн. Джерело / пер. $з$ англ. Олена Замойська.3-е вид. К.: Наш формат, 2018. 752 с.

44. Копнин П. В. Проблемы диалектики как логики и теории познания. Избранные философские работы / отв. ред. В. А. Лекторский. М.: Наука, 1982. 368 с.

45. Smith Antony D. S. Nationalism in Twentieth Century. Canberra: Australian National University Press, 1979. 257 p.

46. Челлен Р. Государство как форма жизни / пер. со шведского и прим. М. А. Исаева; предисловие и примечания М. В. Ильина. М.: РОССПЭН, 2008. 319 с.

47. Тойнби А. Постижение истории: сборник / пер. с англ. Е.Д. Жаркова; сост. А.П. Огурцов; вступ. ст. В.И. Уколовой. М.: Прогресс, 1991. 736 с.

48. Trump's NAFTA Changes. URL: https://www.thebalance.com/donald-trump-nafta-4111368

\section{Идеи Ульриха Бека в контексте современных методологических поисков в мировой социологии}

В статье осуществлена реконструкция системы и метода немецкого социолога Ульриха Бека. Показана важность этой работы в методологической ситуации, которая сложилась в современной социологии и обусловлена изменениями в социальном мире и четвертой научной революцией. Значительная часть понятий, входящих в понятийные сети различных парадигм современной социологии, сфрормировались еще во время второй научной революции. Кроме того, социологи, исследуя современность, сталкиваются с воздействием ненаучных обстоятельств, в качестве которых выступают глобальные угрозы, давление правящих классов и др. Ульрих Бек обогатил мировую социологию концепциями общества риска, Второго модерна, космополитизма. Важное значение имеет его критика методологического национализма. Его призыв к преодолению «понятий-зомби» и сегодня сохраняет свою актуальность. Вместе с тем, немецкий социолог, призывая к новой утопии, видел путь к космополитической фредерации государств с разделенным суверенитетом в налаживании сотрудничества между капиталом, государствами и гражданским обществом. Однако реальных механизмов этого сотрудничества он предложить не смог. Для прогрессивного сдвига проблематики современности полезным может быть синтез идей теории Второго модерна, социологии творческого марксизма, мир-системного анализа и экологической социологии. До настоящего времени эти традиции разделены барьерами непонимания и конкуренции за интеллектуальную новизну. В теории Второго модерна недостатком является сильная контекстуальная зависимость от текущей политической ситуации. У. Бек создавал свои тексты как комментарии к текущим процессам. Для идейного синтеза необходимо не просто воссоздать ход мысли социологов, а представить их идеи в виде связных концепций в контексте требований новой методологической ситуации. Второй модерн и такая его характеристика, как глобализация могут рассматриваться как этап в развитии мировой капиталистической системы. Идея общества риска может резонировать с разработками экологической социологии. Критика неолиберализма в социологии творческого марксизма может обеспечить больиую предметность идее космополитизма. Но для этого необходимо сделать реконструкцию понятийных рядов этих исследовательских направлений, их методологических установок в связи с фрилософрским основами присущего им метасоциологического знания.

Ключевые слова: Ульрих Бек, методология, Модерн, Второй модерн, общество риска, космополитизм, методологический национализм. 


\section{References:}

1. Beck, U. (2001) What is Globalization? The errors of globalism are the answers to globalization, translation from German by A. Grigoriev and V. Sedelnik, afterword and ed. A. Filippov, Progress-Traditsiya, Moscow [in Russian]

2. Savage M. and Burrows R. (2007) The Coming Crisis of Empirical Sociology [online]. Available at: https://pdfs.semanticscholar.org/b909/936b4c3d5ca8be06887ae8780df325b6e154.pdf

3. Yu Xie. (2005), Methodological contradictions of contemporary sociology. Michigan Quarterly Review. Summer, Volume XLIV, Issue 3 [online]. Available at: https://quod.lib.umich.edu/cgi/t/text/textidx?cc=mqr;c=mqr;c=mqrarchive;idno=act2080.0044.318;view=text;rgn=main; $x c=1 ; g=$ mqrg

4. Bulekbayev, S. B., Temirgaliyev, K. A., Lamanova, A. S., Mingisheva, N. A. and Raikhanova, A. N. (2017) Methodological crisis of contemporary social sciences: the theoretical aspect. [online]. Available at: https://cyberleninka.ru/article/n/methodological-crisis-of-contemporary-social-sciences-the-theoretical-aspect

5. Stepin, V. S. (2006) Philosophy of Science. Common problems. Moscow: Gardariki [in Russian]

6. Doctorov, B. Z. (2006) Founding Fathers: A History of the Study of Public Opinion. Moscow: Tsentr sotsialnogo prognozirovaniya [in Russian].

7. Merton, R. (2006) Social Theory and Social Structure. Translation from English. M.: AST; AST MOSKVA; Hranitel.

8. Weber, M. (1990) Selected Works. Translated from German. Comp., total. ed. and afterword Yu. N. Davydova; Foreword P. P. Gaidenko. M.: Progress. (Sociological Thought of the West) [in Russian].

9. Durkheim, E. (1995) 'The Rules of Sociological Method'. Emil Durkheim Sociology. Subject, method, purpose. Translated from Fr., compilation, afterword and notes by A. B. Hoffmann. Moscow: Canon [in Russian].

10. Kononov, I. F. (2016) 'Sociology in times of crisis and war: problem of the methodological efficiency', Visnyk Luhanskoho natsionalnoho universytetu im. Tarasa Shevchenka. Sotsiolohichni nauky. Luhansk Taras Shevchenko National University. №5 (302), pp. 5-55 [in Ukrainian].

11. Derluguian, G. M. (2013) How the world works. Outline on sociological. Moscow: Izd-vo Instituta Gaydara [in Russian].

12. Bauman, Z. (2008) Liquid Modernity. Translated from English. in Yu. V. Asochakova ed. St. Petersburg: Piter [in Russian].

13. Chernilo, D. (2006) 'Social Theory’s Methodological Nationalism Myth and Reality'. European Journal of Social Theory. V. 9. N. 1. 5-22.

14. Chernilo, D. (2007) 'A Quest for Universalism Re-assessing the Nature of Classical Social Theory's Cosmopolitanism'. European Journal of Social Theory. V. 10. N.1, pp. 17-35.

15. Chernilo, D. (2007) A Social Theory of the Nation-State: The Political Forms of Modernity Beyond Methodological Nationalism. London: Routledge.

16. Khan, S. How cosmopolitan is Ulrich Beck's Cosmopolitanism? [online]. Available at: https://www.academia.edu/14067685/Ulrich_Becks_Cosmopolitanism.

17. Martell, L. (2008) ‘Beck’s cosmopolitan politics’, Contemporary Politics. June. Vol. 14. No. 2. pp. 129-143.

18. Martell, L. (2009) 'Global Inequality, Human Rights and Power: A Critique of Ulrich Beck’s Cosmopolitanism'. Critical Sociology. V. 35. N. 2. pp. 253-272.

19. Martell, L. (2011) 'Cosmopolitanism and Global Politics'. Political Quarterly. Autumn. V.18. N. 4. pp. 618-627.

20. Saito, H. (2015) 'Cosmopolitics: towards a new articulation of politics, science and critique'. The British Journal of Sociology. Volume 66. Issue 3. pp. 441-459.

21. Schiller, N. G., Darieva, T. and Gruner-Domic, S. (2011) 'Defining cosmopolitan sociability in a transnational age. An introduction'. Ethnic and Racial Studies. V.34. N.3. pp. 399-418 [online]. Available at: http://dx.doi.org/10.1080/01419870.2011.533781

22. Schiller, N. G. (2010) 'Old baggage and missing luggage: a commentary on Beck and Sznaider's 'Unpacking cosmopolitanism for the social sciences: a research agenda'. The British Journal of Sociology. URL: https://doi.org/10.1111/j.1468-4446.2009.01297.x

23. Skrbis, Z. and Woodward, I. (2007) 'The ambivalence of ordinary cosmopolitanism: Investigating the limits of cosmopolitan openness'. The Sociological Review. V. 55. N. 4. pp. 730-747.

24. Guivant, J. S. (2016) 'Ulrich Beck’s legacy’. Ambiente \& Sociedade. São Paulo. Jan.-mar. V. XIX, №1. pp. $227-237$.

25. Kravchenko, S. A. (2011) 'U. Beck: a sociological imagination that is adequate to the reflexive modern'. Sociological Studies. № 8. pp. 17-27 [in Russian].

26. Kolisnyk, O. V. (2015) 'Reflexive modernization: the problem of interpretation’. Grani, February. № 2 (118). pp. 68-72 [in Ukrainian]

27. Francot, L. M. A. and de Vries, U. R. M. T. (2008) 'Normativity in the Second Modernity'. Rechtstheorie. Berlin. N. 39. pp. 1-18.

28. Bosco, E. and Marques di Giulio, G. (2015) 'Ulrich Beck: Considerations on his contributions and challenges to the Studies in Environment and Society’. Ambiente \& Sociedade. São Paulo. Abr.-jun. V. XVIII, № 2. pp. 145-156.

29. Guivant, J. S. (1998) 'A Trajetória das Análises de Risco: Da Periferia ao Centro da Teoria Social'. BIB. Rio de Janeiro. № 46(2). pp. 3-38.

30. Jarvis, D. S. L. (2007) 'Risk, Globalisation and the State: A Critical Appraisal of Ulrich Beck and the World Risk Society Thesis'. Global Society. January. Vol. 21. No. 1. pp. 23-46. DOI: $10.1080=13600820601116468$

31. Pichlak, M. (2017) Regulating Risk and a Theory of Social Reflexivity of Law [online]. Available at: https://www.academia.edu/38383281/Regulating_Risk_and_a_Theory_of_Social_Reflexivity_of_Law

32. Sørensen, M. P. (2017) 'Ulrich Beck: exploring and contesting risk'. Journal of Risk Research [online]. Available at: https://doi.org/10.1080/13669877.2017.1359204

33. Ivanov, D. V. (2002) 'Evolution of the concept of globalization, Teleskop. St. Petersburg. No. 4. pp. 3 -14 [in Russian]. 
34. 'Sociology: profession and vocation. Interview with Professor Ulrich Beck. Conducted by V. V. Kozlovsky" (2003) The Journal of Sociology and Social Anthropology. Volume VI. No. 1. pp. 5-23.

35. Beck, U. (2003) Cosmopolitan society and its enemies. Translation by Khokhlova, A. M. Journal of Sociology and Social Anthropology. Volume VI. No. 1. pp. 24-53 [in Russian].

36. Beck, U. (2015) Power in the Global Age: A New Global Political Economy. Translated by Yudin, A. 2nd edition. Kyiv: Nika-Tsentr [in Ukrainian].

37. Rozov, M. A. (2006) Theory of social relay races and problems of epistemology. Smolensk: Smolensk State University. (Library of the international colloquium "Social Transformations") [online]. Available at: http://rozova.org/images/documents/SSRozovaTSEvIstorii.pdf (in Russian)

38. Christiansen, A. Bibliography over Ulrich Becks tyske, engelske, norske, svenske og danske udgivelser [online]. Available at: http://www.slagmark.dk/slagmark34

39. Beck, U. (2012) 'Living in and Coping with World Risk Society: The Cosmopolitan. Translation from German Malakhov, V.S. Polis. No5. pp. 44-58 [in Russian].

40. Beck, U. (2000) Risk Society: Towards a New Modernity. Translation by Sedelnik, B. and Fedorova, N. Moscow: Progress-Traditsiya [online]. Available at: http://web-local.rudn.ru/weblocal/prep/rj/files.php?f=pf_eaaf4f79b02a78b919aca693a8e6b572 [in Russian]

41. Beck, U. (1994) From an industrial society to a risk society. Translate by Kovalev, A. D. Thesis. Issue. 5, pp. 161-168 [in Russian].

42. Beck, U. (2009) Critical Theory of the World Risk Society. Cosmopolitan view of the problem. Translate by Markov, A. Prognozis. №2 (18). pp. 3-32 [in Russian].

43. Rand, A. (2018) The Fountainhead. Translate by Zamoyska, E. 3 view. Kyiv: Nash format [in Russian]

44. Kopnin, P. V. (1982) Problems of dialectics as a logic and theory of knowledge. Selected philosophical works. in Lektersky, V. A. (ed). Moscow: Nauka [in Russian].

45. Smith, A. D. S. (1979) Nationalism in Twentieth Century. Canberra: Australian National University Press.

46. Kjellén, R. (2008) The state as a form of life. Translated by Isaev, M. A. Foreword and notes by Ilyin, M. V. Moscow: ROSSPEN [in Russian].

47. Toynbee, A. (1991) Understanding History. Collection. Translated by Zharkov, E. D. Comp. Ogurtsov, A. P. Moscow: Progress [in Russian].

48. Trump's NAFTA Changes [online]. Available at: https://www.thebalance.com/donald-trump-nafta-4111368 